\title{
ELECTRIC, HYBRID ELECTRIC AND FUEL CELL VEHICLES FOR CONTROLLING AUTOMOTIVE POLLUTION IN INDIA
}

\author{
Vyom Bhushan ${ }^{1}$, Veerbhadrappa ${ }^{2}$ \\ ${ }^{1}$ M.Tech Student, Automobile Engineering, R.I.T., Islampur, Maharashtra, India \\ ${ }^{2}$ Asst. Professor, Automobile Engineering, IOK COE, Pune, Maharashtra, India
}

\begin{abstract}
In today's world, there is the need of the vehicles having low emissions, efficient for city driving, long distance travelling capability and high cruising ability with high fuel economy. These all requirements can easily be fulfilled by electric vehicles, hybrid electric vehicles and fuel cell vehicles as the electric vehicles run on electric power, the hybrid electric vehicles can run on engine power or motor power or combined power of both engine and motor. This paper is mainly focussed to the hybrid electric vehicles and their types, series, parallel as well as the series-parallel combined hybrid vehicles with their advantages, disadvantages and applications along with the type of degree of hybridization and fuel cells used in hybrid fuel cell vehicles have been explained with their different types, proton exchange membrane, alkaline, phosphoric acid, molten carbonate, solid oxide and direct methanol fuel cells with application. The fuel cell vehicles are more beneficial than the electric as well as hybrid electric vehicles in as the fuel cell vehicles have high efficiency and these vehicle are the recent trends in the latest technologies and lots of researches are going on the fuel cell vehicle by Japanese automotive manufacturers like Toyota and Honda and these fuel cell vehicles can accomplish the need of controlling automotive pollution in India as the fuel cell vehicles have zero emission. Also, these vehicles can be refuelled in less time, in just 3-4 minutes and can run long distances up to 500 kilometres with full performance. The fuel cell vehicles are also available in sedans.
\end{abstract}

Keywords: EV, HEV, Hybridization, Fuel Cells And Fuel Cell Vehicles

\section{INTRODUCTION}

Hybrid electric vehicles are the need of today's world as they have very less emissions in comparison to the conventional vehicles. Generally, hybrid electric vehicles use an engine with an electric motor coupled in such a way as to decrease the emissions of the vehicle at low speed and to enhance the performance at high speed when the vehicle is needed to be cruised on highway. These vehicles are more efficient than the conventional vehicles in various aspects such as vehicle emission, fuel economy, flexibility to switch between electric and internal combustion engine power.

\section{ELECTRIC VEHICLES}

Electric vehicles may be considered as the vehicles which have electric motors for traction and their energy sources are fuel cells, chemical batteries, flywheels and ultracapacitors. There is no emission by electric vehicles and thus the problem of pollution has been automatically solved by the use of these vehicles. ${ }^{[5]}$ The motion of the vehicle takes place due to the conversion linkage system of electromechanical energy and this system is used between the wheels and the energy source of the vehicles.

\subsection{Components}

The components of a modern electric vehicle has been shown in Fig-1. There are several components in an electric vehicles which are divided into three main subsystems namely electric motor propulsion, energy source, and auxiliary. The controller, electric motor, electronic converter, conventional transmission and driving wheels comes in electric motor propulsion subsystem whereas the energy source, energy management unit and energy refueling unit comes in energy source subsystem and the power steering unit, the climate control unit and the auxiliary supply unit falls in auxiliary subsystem. ${ }^{[1]}$

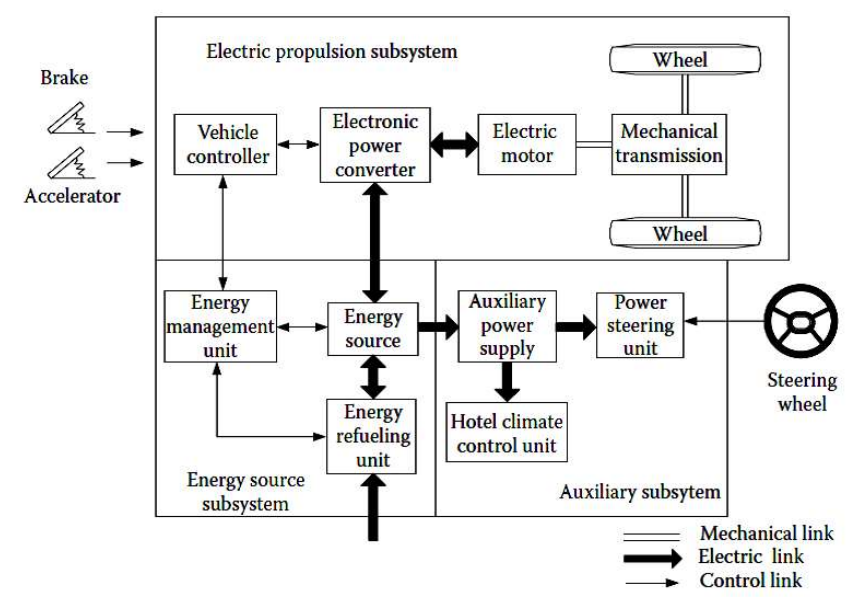

Fig-1: Components of Modern Electric Vehicle ${ }^{[1]}$

\subsection{Applications of Electric Vehicles}

The electric vehicles are mainly used for city driving purpose where only short distances are needed to be covered and vehicle maximum speed is needed to be limited as the electric vehicle can easily be driven in consisted areas of the city as in general practice, the electric vehicles are made in 
small size and also these vehicles have zero emission means that there is no emission from these vehicles. ${ }^{[5]}$ So, these vehicles save the environment from pollution as they are eco-friendly in nature and cheaper than hybrid electric vehicles. The electric vehicles have nearly zero maintenance and are easier to drive in the city. Nissan LEAF is an example of an electric vehicle.

\section{HYBRID ELECTRIC VEHICLES}

A hybrid vehicle has two or more powertrains in it. If any hybrid vehicle uses an internal combustion engine coupled with electric powertrain then that vehicle is said to be a hybrid electric vehicle. ${ }^{[7]}$ In a HEV, a battery is used to store the electrical energy and an electric motor is used as a traction motor to produce the traction needed to move the vehicle from stationary condition.

In a hybrid vehicle, constant power is provided by the internal combustion engine. Generally, the small sized engine is used as the dynamic power is produced by the electric motor which is powered by the battery and the motor acts as a source for the dynamic power needed in the vehicle.

\subsection{Series Hybrid Vehicles}

In these type of vehicles, the wheels are not driven directly whereas the electric generator is driven by the internal combustion engine as shown in Fig-2. The electric generator has 3-phase alternator with a rectifier. The generator gives the power to the electric motor which further sends the power to the wheels so as to move the vehicle. When there is the need of a high power the electric generator as well as the battery both gives the power to the electric motor independently, to move the vehicle at a high speed. ${ }^{[4]}$

In general, the series hybrid vehicles use either a flywheel or sometimes an ultracapacitor to increase the efficiency by reducing the battery losses. The maximum energy is delivered at the time of acceleration and the battery is charged by taking the regenerative energy at the time of braking the vehicle. ${ }^{[2]}$ So, for this purpose, at low speed the ultracapacitors are charged and when the vehicle attain its maximum speed, the ultracapacitors become exhausted.

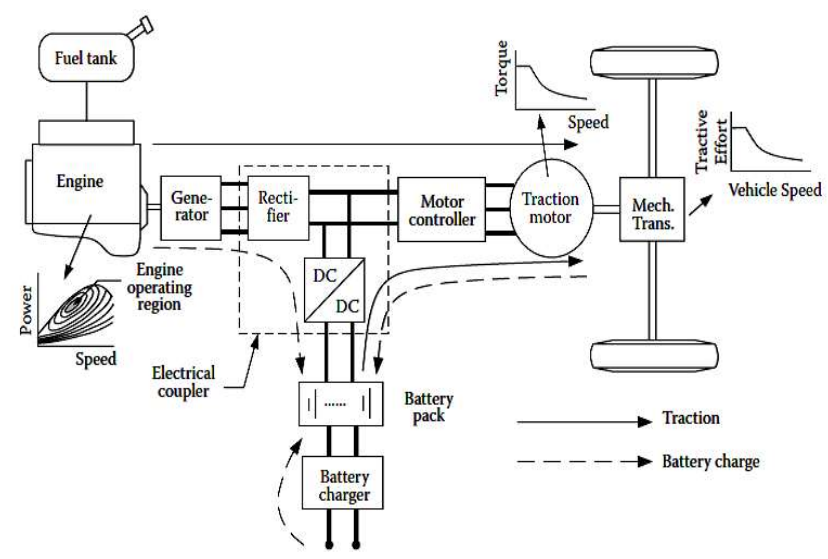

\subsubsection{Advantages of Series Hybrid Vehicles}

- No mechanical linkage is present between internal combustion engine and wheels.

- No transmission is present in this type of vehicles.

- Most efficient for city driving.

\subsubsection{Disadvantages of Series Hybrid Vehicles}

- More weight.

- Large size.

- High Cost.

\subsection{Parallel Hybrid Vehicles}

In parallel hybrid vehicles, both internal combustion engine and electric motor are connected in parallel with each other. In this type of drivetrain, the power is supplied from engine to the wheels of the vehicle like conventional vehicles. ${ }^{[4]}$ The power of internal combustion engine and the power of electric motor are coupled and added by using mechanical coupler as shown in Fig-3.

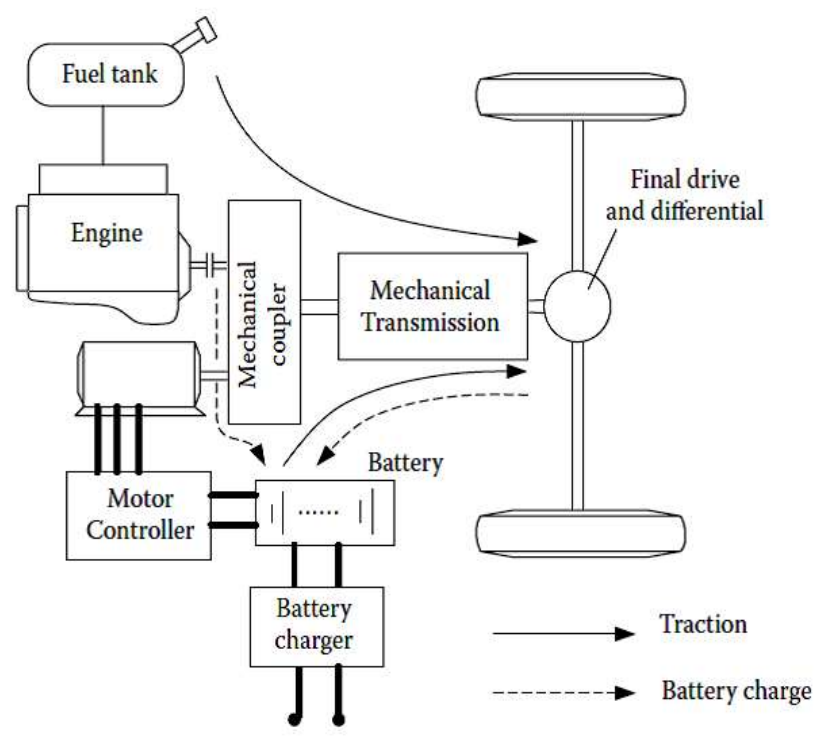

Fig-3: Parallel Hybrid Vehicle Configuration ${ }^{[1]}$

In general, the mechanical coupling is the combination of torque coupling and the speed coupling. The engine torque and motor torque are added to mechanical torque coupling and both torques are controlled independently, but the engine speed, the motor speed and the vehicle speed cannot be controlled in an independent manner.

In mechanical speed coupling, the engine speed and the speed of electric motor can be added but the engine torque and torque of electric cannot be controlled.

\subsubsection{Advantages of Parallel Hybrid Vehicles}

- Higher cruising capability.

- Longer distance highway driving capability.

- Only electric motor is needed.

Fig-2: Series Hybrid Vehicle Configuration ${ }^{[1]}$ 


\subsubsection{Disadvantages of Parallel Hybrid Vehicles}

- More complex than series hybrid.

- Efficiency decreases when the rotational speed is low.

- The charging of battery is not possible when the vehicle is stationary.

\subsection{Series-Parallel Combined Hybrid Vehicles}

The series-parallel combined hybrid vehicles are the combination of both series as well as parallel hybrid vehicles. ${ }^{[8]}$ There are mechanical and electrical connections between and engine and drive axle as shown in Fig-4.

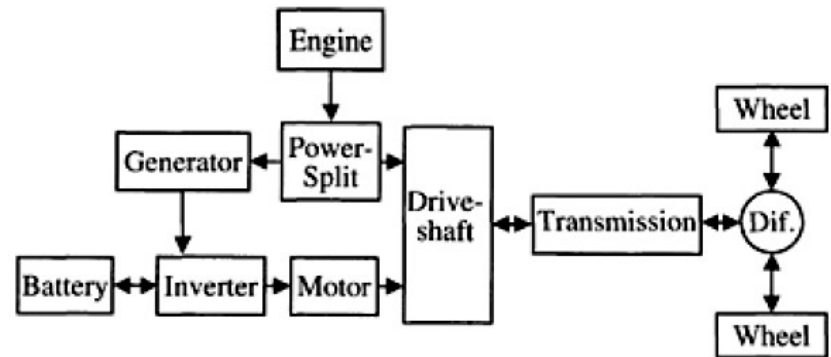

Fig-4: Series-Parallel Combined Hybrid Vehicle Configuration $^{[2]}$

So as to interconnect the mechanical and electrical power, the power-split devices are introduced to the vehicle. The power can be transmitted to the wheels either mechanically or electrically or combined. Generally, a large hybrid engine is used in a conventional vehicle for better acceleration at a high speed. But, in case of combined hybrid vehicles, the electric motor produces a high torque at stall and even better engine torque at low engine speed. The small hybrid engine is used in combined vehicles which gives better overall vehicle efficiency with regenerative braking.

\subsubsection{Advantages of Parallel Hybrid Vehicles}

- High switching flexibility between power of the internal combustion engine and power of the electric motor.

\subsubsection{Disadvantages of Parallel Hybrid Vehicles}

- More complex than parallel hybrid vehicles.

- Higher cost in comparison to parallel hybrid vehicles.

\subsection{Applications of Hybrid Electric Vehicles}

The hybrid electric vehicles are mainly used for highway cruising with minimum emission and with maximum possible fuel economy as most of the times these vehicles are used to prevent the environment from pollution because most of the highway cruising vehicles pollute the environment as they are not eco- like the hybrid electric vehicles.

\section{TYPES OF DEGREE OF HYBRIDIZATION}

The major four types of degree of hybridization are as follows:

\subsection{Full Hybrid}

The full hybrid electric vehicle can run either on internal combustion engine or electric motor or the combined power of internal combustion engine and electric motor. ${ }^{[3]}$ There is a need of large capacity battery for a full hybrid vehicle. Toyota Prius is the example of full hybrid vehicle.

\subsection{Mild Hybrid}

Generally, the primary power is taken from the internal combustion engine and the torque is boosted by the electric motor having high torque producing capacity. Both the engine as well as the motor are connected in parallel to the powertrain as shown in Fig-5. The electric motor also acts as an electric generator when regenerative braking takes place in a mild hybrid vehicle. ${ }^{[3]}$ Honda Civic Hybrid and Honda Insight are the examples of mild hybrid vehicles.

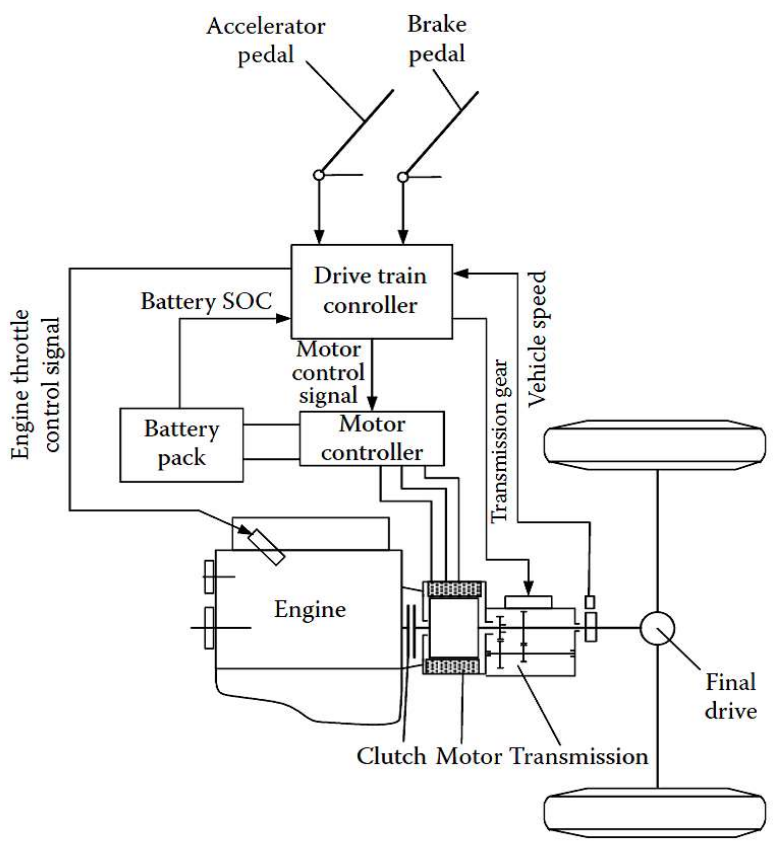

Fig-5: Mild Hybrid Vehicle Configuration ${ }^{[1]}$

\subsection{Micro Hybrid}

The micro hybrid vehicles have the feature of auto start-stop which is very beneficial for city driving. These vehicles are generally equipped with large sized starter motor which turns the engine off when the vehicle is stopped for a short period of time and while restarting, the starter motor cranks the engine up to the operating speed before fuel injection. ${ }^{[3]}$ Mahindra Scorpio Micro Hybrid is the example of micro hybrid vehicle.

\subsection{Plug-in Hybrid}

The vehicles which are full hybrid but can also run on electric motor only as they have the charging slot with the help of which the battery can easily be charged at any point are known as plug-in hybrid vehicles. ${ }^{[3]}$ The vehicle can run for long distances in one-time charging of the battery which is much better than a full hybrid vehicle. BMW i8 is the example of plug-in hybrid vehicle. 


\section{FUEL CELL VEHICLES}

There is a fuel storage system in a fuel cell electric vehicle. Fuel storage system has a fuel processor which converts raw fuel to hydrogen. It also has a fuel cell stack with its control unit, a power processing unit with its controller and the propulsion unit with drivetrain and the electric machine. ${ }^{[7]}$

The fuel cell works like a current source and has low output voltage. To get high voltage various fuel cells are connected in series and after it the output voltage is booted so as to interface with direct current or alternating current inverter, which drives an alternating current propulsion motor. To obtain high power density an alternating current motor is used ${ }^{[8]}$ Fig-6 shows the block diagram of a fuel cell.

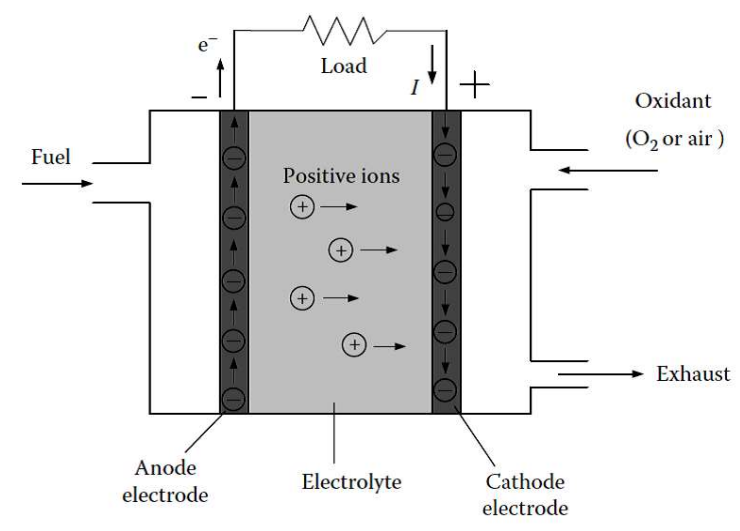

Fig-6: Block Diagram of a Fuel Cell ${ }^{11}$

The series hybrid configuration is used in fuel cell vehicles with a battery which gives peak acceleration power so as to reduce the size and power restraints on the fuel cell.

A fuel cell is nothing but a galvanic cell in which electrochemical process takes place to convert the chemical energy of a fuel into electrical energy. The oxidizing agent and fuel undergo a chemical reaction at the two electrodes of the cell. The electrolyte is required to move ions from one electrode to the other.

When fuel is given to the anode which works as positive electrode, the electrons are released from the fuel in presence of a catalyst. As the two electrons are at different potential creating a potential difference between the two electrodes, the electrons move to the cathode which works as negative electrode, combination of positive ions and oxygen takes place and exhausts or reaction products are produced.

\subsection{Types of Fuel Cells}

\subsubsection{Proton Exchange Membrane Fuel Cells}

The electrolyte used in proton exchange membrane fuel cells is a solid polymer membrane. The polymer membrane is nothing but a perfluorosulfonic acid.

As this polymer is acidic in nature so protons or hydrogen ions are transported. The proton exchange membrane fuel cells are used as a fuel with hydrogen and air. Carbon supported catalyst is used by coating it on the polymer electrolyte membrane. The catalyst remains in contact with the diffusion layer and the electrolyte. ${ }^{[6]}$ The combination of gas diffusion layers, catalyst layers and electrolyte is called membrane-electrode assembly.

The efforts have been made to improve catalyst technology so as to reduce the loadings of platinum. The fuel cells work at low temperature and electrolyte is acidic in nature so noble metals are used for catalytic layer. There is difficulty in the catalytic reduction of oxygen while the oxidation of hydrogen is not so difficult. The water, which is formed at cathode, is carried out of the fuel cells in the form of a vapour.

\subsubsection{Alkaline Fuel Cells}

Potassium hydroxide is used in the form of an aqueous solution as the electrolyte in alkaline fuel cells. The electrolyte is alkaline in nature so hydroxide ion is carried by it. Here in the case of alkaline fuel cells water is formed on hydrogen electrode and the reduction of oxygen requires water at the cathode. Water is kept in the electrolyte and electrodes are made waterproof to manage the water problem. The water is consumed by the cathode reaction from the electrolyte while the water is rejected by the anode reaction and the evaporation of excess water takes place.

\subsubsection{Phosphoric Acid Fuel Cells}

Phosphoric acid fuel cells use an acidic electrolyte to carry hydrogen ions. Cathode and anode reactions are similar to proton exchange membrane fuel cells reactions. Cheap electrolyte is needed for phosphoric acid fuel cells. Besides this, average start-up time and low operating temperature may be taken as the main advantages of these fuel cells. ${ }^{[6]}$ There are some disadvantages also, which include low efficiency, expensive catalyst platinum, corrosion by acid electrolyte and poisoning carbon monoxide.

\subsubsection{Molten Carbonate Fuel Cells}

These cells are high temperature fuel cells as they work at temperature nearly $500^{\circ} \mathrm{C}$ to $800^{\circ} \mathrm{C}$. Molten carbonate salts such as lithium-sodium carbonate or lithium-potassium carbonate, are used to carry out carbonate ions. The mechanism of ion movement is similar to the mechanism in phosphoric acid fuel cells. ${ }^{[6]}$ The main difference from other fuel cells is the supply of $\mathrm{CO}_{2}$ at the cathode, which is done by recycling it from the anode. Molten carbonate fuel cells are always used with hydrocarbons.

At high temperature, hydrocarbon fuels decompose to hydrogen on the electrodes. Thus, available hydrocarbon fuels may be used for automotive purposes. ${ }^{[6]}$ High temperatures increase the kinetics to such an extent that it may be possible to use cheap catalysts.

The major advantages of molten carbonate fuel cells are as follows:

- They are used as a fuel with hydrocarbon fuels.

- They need low cost catalysts. 
- The efficiency is high due to the increased kinetics.

- The sensitivity to poisoning is low.

The major disadvantages of molten carbonate fuel cells are as follows:

- Corrosive electrolyte.

- Slow start-up.

- Slow power response.

- Complex fuel cell system.

\subsubsection{Solid Oxide Fuel Cells}

In these fuel cells ions are carried out in a ceramic membrane at very high temperature of the range $1000^{\circ} \mathrm{C}$ to $1200^{\circ} \mathrm{C}{ }^{[6]}$ The mechanism of ion movement is like solidstate devices. Activation losses are low because the operating temperature is very high. There are two types of solid oxide fuel cells which are as follows:

- Tubular

- Planar

\subsubsection{Direct Methanol Fuel Cells}

Methanol is used as the for these cells, so they are called direct methanol fuel cells. There are following advantages of using these fuel cells to the vehicles ${ }^{[6]}$ :

- Methanol is found in liquid form, so it is very easy to handle and to use it in a vehicle.

- The use of methanol is economic.

- The methanol can be produced easily on commercial scale.

\subsection{Application of Fuel Cells}

The fuel cells are used in fuel cell vehicles which are more beneficial than electric vehicles and hybrid electric vehicles in various aspects such as efficiency. So, they are introduced as the passenger vehicles to the automobile market by different automotive manufacturers. Toyota Mirai is the example of fuel cell vehicle.

\section{CONCLUSION}

The present paper tries to explain the application of electric vehicles with its components. The paper is mainly focused to the hybrid electric vehicles with advantages, disadvantages and applications along with the types of degree of hybridization as per the vehicles available in today's world. Also, the fuel cells generally used in hybrid electric fuel cell vehicles have been explained with their different types in such a manner to give a exact idea of them with their advantages, disadvantages and applications.

\section{REFERENCES}

[1] Ehsani, Mehrdad, Gao, Yimin and Emadi, Ali, "Modern Electric, Hybrid Electric, and Fuel Cell Vehicles: Fundamentals, Theory, and Design", Second Edition, CRC Press, U.S.A., 2010.

[2] Husain, Iqbal, "Electric and Hybrid Vehicles: Design Fundamentals", CRC Press, U.S.A., 2005.
[3] Pistoia, Gianfranco, "Electric and Hybrid Vehicles: Power Sources, Models, Sustainability, Infrastructure and the Market", First Edition, Elsevier, Great Britain, 2010.

[4] Miller, John M., "Propulsion Systems for Hybrid Vehicles", Second Edition, The Institution of Engineering and Technology, London, United Kingdom, 2010.

[5] Hodkinson, Ron and Fenton, John, "Lightweight Electric/Hybrid Vehicle Design", First Edition, Butterworth-Heinemann, Jordan Hill, Oxford, 2001.

[6] Erjacev, Jack, "Hybrid, Electric \& Fuel-Cell Vehicles", Second Edition, Delmar, Cengage Learning, U.S.A., 2013.

[7] Anderson, Curtis D. and Anderson, Judy, "Electric and Hybrid Cars: A History", Second Edition, McFarland \& Company, Inc., Publishers, U.S.A., 2010.

[8] Khan, Mariam and Kar, Narayan C., "Hybrid Electric Vehicles for Sustainable Transportation: A Canadian Perspective", World Electric Vehicle Journal, International Battery, Hybrid and Fuel Cell Electric Vehicle Symposium, Vol. 3, 2009.

[9] Miller, John M., "Hybrid Electric Vehicle Propulsion System Architectures of the e-CVT Type", IEEE Transactions on Power Electronics, Vol. 21, No. 3, pp. 756-767, May 2006.

\section{BIOGRAPHIES}

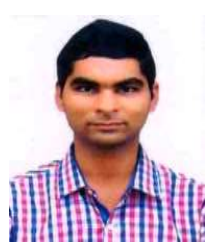

Vyom Bhushan, M.Tech First Year, Automobile Engineering Dept. R.I.T., Islampur, Dist. Sangli-415414, India

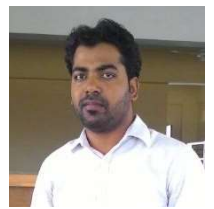

Prof. Veerbhadrappa, Assistant Professor, Automobile Engineering Dept. IOK College of Engineering

Pune-412208, India 